\title{
Challenges of Grading in an ESP Course
}

\author{
Iryna Didenko \\ $\mathrm{PhD}$, Taras Shevchenko National University of Kyiv \\ Nataliia Zhukova \\ PhD, Zaporizhzhia National Technical University
}

\begin{abstract}
This paper deals with the drawbacks of the existent grading system in the English for Specific Purposes course and the suggested solution to this problem. The main difficulty concerns the fact that in Ukraine the CEFR level is not mentioned in the transcript of the university diploma containing the list of the courses and their grades. This is the reason of impossibility to split students into groups according to their initial level of English language competency and give them an opportunity to develop at an appropriate pace and rate. Thus, we can not completely meet the needs of our students, although satisfying the learners' needs is the key point in an ESP course. This discrepancy pushed us, ESP practitioners, to reconsider our approach to the grading system in an ESP course. We have suggested a system of level ratio that may be applied while calculating the final grades of the students. The introduction of this system may eliminate the outlined problem and enchance motivation of university students in an ESP classroom. In this paper we have described the mechanism of level ratio application, depicted the advantages of the suggested theory and outlined possible problems that can appear.
\end{abstract}

Keywords: grading, level ratio, fairness, transparency of grades, motivation, needs, CEFR, European Credit Transfer and Accumulation System, assessment, English for Specific Purposes

\section{Introduction}

In any English for Specific Purposes (ESP) course, assessment should reveal some relationship between the language, subject-related skills and knowledge that a person needs to master in order to perform efficiently in the professional environement.

The reasons for assessment are grouped under 2 main headings: for feedback to aid learning and for a comparable measure of competence (Dudley-Evans, T. \& St. John, M. J., 2013, p. 210). And when assessment is regarded as "a process of measuring" (Dudley-Evans, T. \& St. John, M. J., 2013, p. 210), grades come into the foreground of educational process.

Ukraine has been a full member of the Bologna Process / European higher education area since 2005 (Members, n.d.). Therefore, Ukrainian higher education institutions make use of the European Credit Transfer and Accumulation System (The ECTS Tables and Grading Scale, n.d.), which is "a tool for making studies and courses more transparent and thus helping to enhance the quality of higher education" (ECTS Users' Guide, 2015, p. 6), "designed to facilitate the transfer of academic results (expressed in terms of grades) between different national assessment systems" as they "allow the conversion of the grades from one country into grades used in another country, following common European rules" (The ECTS Tables and Grading Scale, n.d.).

Nowadays grades are not a mere formal requirement. Depending on the grades students may be obliged to retake some exams, be more or less successful when applying for a job, and, above all, their motivation and self-confidence are either enhanced or undermined. What is more, transparency of grades is significant regarding the current growth of academic mobility programs as level of performance influences students' access to further studies, grants or other benefits (ECTS Users' Guide, 2015, p. 39). Hence, fairness and standardization of grading are vital. 


\section{Methods}

The study required the application of the following methods: hypothetico-deductive method was used to formulate the theory that accounts for the results obtained via direct observation and enables to predict further effects to be verified or disproved by empirical evidence; comparison was necessary to correlate the existing grading system with the suggested one; analysis and synthesis were applied to identify the relations between the existing grades and the introduced ones regarding the level ratio, induction helped to summarize the prospects for the usage of the suggested level ratio for grading, quantitative method was used to calculate the ratio.

\section{Results}

Every year, when yesterday's school leavers enter our universities we encounter one and the same problem: their level of the English language competency ranges from A1 to $\mathrm{C} 1$. There is no opportunity to split them into groups according to their level. The reasons are as follows: we do not indicate the level according to CEFR classification in the transcripts to the diplomas; the only two things are mentioned there: the name of the course - English for Specific Purposes and the grade. Therefore, if we do streaming, split students into different groups according to their level, use course books of the appropriate level, we may face an unfair situation, when an A2 level student has higher grades than a B2 level student, whilst his or her knowledge and skills are much lower than those of the B2 level student. This may influence not only the result of the competition among students for the right of having scholarship, but later it can cause the situation of misleading the future employers and other stakeholders about the real competencies of this or that graduate.

Besides these challenges the existent assessment system does not allow to pay respect to students' needs, which are considered to be of paramount importance in an ESP course. Moreover, this situation decreases motivation of learners and, as a result, leads to lower productivity, time and effort waste.

All the above mentioned difficulties pushed us to reconsider our approach to assessment in the ESP course. If we can not change the state standards of filling in the transcripts of the diplomas, we can change our approach to calculation of the final grades. Thus, we suggested introducing a level ratio corresponding to each CEFR level. In our opinion, it would be more beneficial for the students to be split into groups according to their level and to have their final grades calculated using level ratio application, as it is shown in the following table.

\begin{tabular}{|c|c|c|c|c|c|c|c|c|c|c|c|c|c|c|}
\hline \multirow{2}{*}{$\begin{array}{l}\text { CEFR } \\
\text { Level }\end{array}$} & \multirow{2}{*}{$\begin{array}{l}\text { Course book } \\
\text { level }\end{array}$} & \multirow{2}{*}{$\begin{array}{l}\text { Level } \\
\text { Ratio }\end{array}$} & \multicolumn{12}{|c|}{ Correspondence of the obtained grades to the level ratio } \\
\hline & & & 100 & 95 & 94 & 90 & 88 & 83 & 79 & 75 & 71 & 67 & 63 & 60 \\
\hline $\mathrm{C} 1$ & Advanced & 1 & 100 & 95 & 94 & 90 & 88 & 83 & 79 & 75 & 71 & 67 & 63 & 60 \\
\hline B2 & $\begin{array}{l}\text { Upper- } \\
\text { intermediate }\end{array}$ & 0.95 & 95 & 90 & 89 & 86 & 84 & 79 & 75 & 71 & 68 & 64 & 60 & - \\
\hline B1 & Intermadiate & 0.9 & 90 & 86 & 85 & 81 & 79 & 75 & 71 & 68 & 64 & 60 & - & - \\
\hline $\mathrm{A} 2$ & $\begin{array}{l}\text { Pre- } \\
\text { Intermadiate }\end{array}$ & 0.85 & 85 & 81 & 80 & 77 & 75 & 71 & 67 & 64 & 60 & - & - & - \\
\hline $\mathrm{A} 1$ & Elementary & 0.8 & 80 & 76 & 75 & 72 & 70 & 66 & 63 & 60 & - & - & - & - \\
\hline $\begin{array}{l}\text { Symb } \\
\text { Greer } \\
\text { Blue I } \\
\text { Red o }\end{array}$ & $\begin{array}{l}\text { bers - grad } \\
\text { ers and red } \\
\text { depicts minir }\end{array}$ & 15 & gra & & stu & ete & $\mathrm{a}$ bo & $\mathrm{dc}$ & ance & the & $\begin{array}{l}\text { ysten } \\
\text { I ratic }\end{array}$ & & & \\
\hline
\end{tabular}

Calculation: 
The final grade put into student's record book = grades obtained by the students according to the traditional ECTS system $x$ level ratio. The final result is rounded according to the mathematical rules.

\section{Example:}

If a student from the group of $\mathbf{B} 2$ level gets 90 , the calculations are as follows: $90 \times 0.95=86$. So the student gets 86 grades into his/her record book.

If a student from the group of $\mathbf{B} 1$ level gets 90 , the calculations are as follows: $90 \times 0.9=81$. So the student gets 81 grades into his/her record book.

Range of final grades for the students of different levels:

A1 level: from 60 to 80

A2 level: from 60 to 85

B1 level: from 60 to 90

B2 level: from 60 to 95

C1 level: from 60 to 100

The suggested grading system has the following advantages:

Fair distribution of grades among students of different levels

Elimination of the risk that strong students with lack of motivation join the lower level groups for the sake of higher final grades

Higher motivation for lower level students to do well in order to be able to join the higher level groups with opportunity to get higher final grades correspondingly

Opportunity for the students of the same year of study to join the group of appropriate to their skills and knowledge level, despite the fact that the level is not mentioned in the transcript of their diploma

Better meeting the students' needs

Meanwhile, this system has a few disadvantages:

Level ratio needs scientific justification and further elaboration.

There is some evidence of discrimination of A1 and A2 level students in terms of their impossibility to get an excellent grade (90), at least while they are a part of Pre-intermediate or Elementary groups.

\section{Conclusions}

The existent assessment system in an ESP course is far from ideal. Therefore, it really needs reconsideration by the competent experts including front-line ESP practitioners. In this paper we suggested our way out of the situation, when students and teachers suffer from lack of opportunity to work in groups of the corresponding level and still have the system of fair and valid assessment. Undoubtedly, the system of final grade calculations in accordance with level ratio needs further elaboration, however, its introduction may be beneficial for the learners in terms of motivation, reasonable amount of challenge and fairness.

\section{References}

[1] Dudley-Evans, T., \& Jo, S. J. (2013). Developments in ESP: A multi-disciplinary approach. Cambridge, United Kingdom: Cambridge University Press.

[2] The ECTS Tables and Grading Scale - University of Bologna (n.d.). Retrieved November 2, 2018, from https://www.unibo.it/en/teaching/enrolment-transfer-and-final-examination/the-university-system/ects-label

[3] ECTS Users' Guide - European Commission. (n.d.). DOI 10.2766/87592. Retrieved November 2, 2018, from http://ec.europa.eu/education/ects/users-guide/docs/ects-users-guide_en.pdf

[4] Members. European Higher Education Area and Bologna Process (n.d.). Retrieved November 2, 2018, from http://www.ehea.info/pid34250/members.html 
